\title{
What Drives Cross-Border Mergers and Acquisitions and Greenfield Foreign Direct Investment Capital Flows? Reconsideration in the Case of the Selected Former Yugoslav Countries
}

\author{
Ksenija Dencic-Mihajlov, Vinko Lepojevic, Jovana Stojanovic*
}

\author{
University of Nis \\ Trg kralja Aleksandra Ujedinitelja 11, 18000 Nis, Republic of Serbia \\ E-mail.ksenija.dencic-mihajlov@eknfak.ni.ac.rs; vinko.lepojevic@eknfak.ni.ac.rs; jovana.stojanovic992@gmail.com \\ *Corresponding author
}

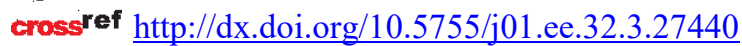

\begin{abstract}
Bearing in mind the different nature and the impact of various types of foreign direct investments (FDI) on the one hand, and the specific macroeconomic environment in the post-socialist countries on the other hand, in this paper we reexamine the selected macroeconomic factors that affect the two types of FDI inflows (cross-border mergers and acquisitions and greenfield FDI) in four countries of the former Socialist Federal Republic of Yugoslavia. The study employs the balanced panel data framework and covers twelve-year period (2006-2017). Having performed the Hausman test, we use the random effect model and provide evidence that: (1) the key FDI macroeconomic determinants in stable business conditions, examined in numerous research studies, can have a different impact on FDI in times characterized by unstability and financial crisis, (2) some determinants of FDI inflows have different importance and direction in the case of cross-border $M \& A$ and greenfield FDI. Our findings are relevant for policymakers who should reconsider the key factors that fuel the FDI inflows towards their developing economies.
\end{abstract}

Keywords: Foreign Direct Investments; Cross-Border Mergers and Acquisitions; Greenfield Foreign Direct Investments; Macroeconomic Determinants; Panel Data Method; Random-Effects Model.

\section{Introduction}

Among the features of the modern economic environment, foreign direct investments (FDI) are an important element of a country's growth and development. This trend is caused by an accelerated globalization, driven by free trade and the investment policy of national governments (Nagano, 2013).

Given that FDI are considered one of the most stable components of capital flows in some countries, this global phenomenon has triggered increasing academic research and numerous discussions on the FDI inflows determinants. Although in the past few years such studies are on the rise, this is not the case with studies that simultaneously explore common determinants of their two forms such as cross-border mergers and acquisitions (cross-border M\&A) and greenfield foreign direct investment (greenfield FDI). Bearing in mind this fact, but also the different nature of the cross-border M\&A and greenfield FDI activities, we consider it justified to engage in a comparative examination of both types of capital investment to identify similarities and differences in their determinants. In such analysiss, the characteristics of the observed countries are included in the model as variables, representing the factors affecting the arrival of foreign investors at a certain market (Basile et al., 2010).

Our study examines macroeconomic determinants of cross-border M\&A and greenfield FDI inflows such as inflation rate, quality of the education system, market capitalization, human development index, openness, public trust in the financial honesty of politicians, unemployment rate and gross domestic product per capita (GDP per capita). Our analysis refers to member countries of the European Union (Republic of Croatia and Republic of Slovenia), as well as to those that are not members yet (Republic of Serbia and Bosnia and Herzegovina). These countries once belonged to one state - the Socialist Federal Republic of Yugoslavia (SFRY), and today they are at different levels of economic development and have different absorption power from the aspect of accepting foreign capital. Since the disintegration of the SFRY, most former republics have been characterized by a weakened institutional and political environment, relatively weak law enforcement and less efficient governance process. The research covers a period of twelve years (2006-2017) and is characterized partly by a financial and economic crisis. Due to different impacts on economic indicators, the period with unstable business conditions is taken for analysis to obtain answers to the question as to whether the analyzed countries managed to recover the weakened macroeconomic market stability after the crisis.

By testing the predicted relationships between selected variables and cross-border M\&A and greenfield FDI inflows, our research points out to the importance of infrastructure prerequisites and macroeconomic policies for the FDI inflows growth in the crisis and post crisis period, and reveals some specific relations between the two analyzed froms of FDI inflows and institutional and economic development of the analyzed former SFRY countries. The contribution of the paper is twofold. Firstly, we extent the comparative empirical analysis of a set of determinants of cross-border M\&A and greenfield FDI inflows, which is deficit in the case of transition economies. 
Secondly, we provide the evidence that some determinants of FDI inflows may have different importance and direction in the case of cross-border M\&A and greenfield FDI.

The paper is structured as follows. The second section provides a literature review, and presents the main macroeconomic factors that will be considered in the paper, as well as the authors' assumptions about their relationship with FDI inflows. The third part of the paper describes the empirical data and the research methodology. After a brief overview of total FDI inflows trends in the former SFRY countries in the analyzed period, the fourth part presents and discusses the research results. In the last part, we provide conclusions, indicate research limitations, and propose goals for future research.

\section{Literature Review}

FDI has received considerable attention in the literature, given the intensified liberalization of investments that in most cases contributes to national wealth (Cai \& KarasawaOhtashiro, 2018, p. 398). The development of the classical theory of international business activities began with the early concept of foreign direct investment. From the middle of the twentieth century various theories have been developed to explain FDI (for a review of FDI theories see: Nayak \& Choudhury, 2014).

The theorethical efforts of an explanation of FDI were attempted in the 1960s with several models based on the assumptions of perfectly competitive market. One of the first theories based on imperfect markets and industrial organization approach was developed by Hymer (1976). Hymer's theory was extended by Kindleberger (1969), who explained FDI activity on the basis of monopolistic power. In their internalization theory, Buckley \& Casson (1976) gave another explanation of FDI by stressing intermediate inputs and technology, and moving attention from countryspecific towards industry and firm-level determinants of FDI. Dunning (1979) incorporated the assumptions the oligopolistic and internalization theory, and explained in his ecletic (OLI) paradigm a set of factors (ownership, location and internalization) that influence the activities of multionational companies (MNC). Aliber (1970) presented the theory of FDI based of the relative strength of the various currencies. Many efforts aimed at integration of FDI theory with the theory of international trade (Vernon, 1966; Kojima \& Ozawa, 1985; Helpman, 1984).

Until the middle of the twentieth century, the primary sector and resource-based production were considered one of the main advantages of an economy, and their availability was an important determinant of the host country. Afterwards, FDI spilled over into the manufacturing sector of developing countries, and the size of the market and its growth have become important determinants for foreign investors. With the new technical-technological order, FDI flowed into industries based on capital, knowledge and skills, and an educated workforce has become an important determinant for foreign investors. Despite the fact that this has led to the creation of new strategies for MNC aiming to improve their competitiveness, traditional determinants remain important to foreign investors (Noorbakhsh et al., 2001).

One of the reasons why countries are interested in attracting foreign investors is that foreign capital has a positive effect on economic growth, depending on the mode of entry into foreign market. Speaking of recent literature, for the purpose of this research, to explain the choice of international foreign investment, its determinants, as well as its impact on economic growth, it is worth mentioning the allocation theory developed by Nocke \& Yeaple (2008). These authors state that the choice of FDI methods varies among host countries depending on the features of the country and its level of development. Their theory suggests that investors will prefer to invest capital in the form of cross-border M\&A in developed countries, which are characterized by smaller differences in costs and lower levels of corporate assets. Developing countries with reverse characteristics attract capital in the form of greenfield FDI.

Considering the impact of these two forms of investment on economic growth, Nocke \& Yeaple (2008) and Harms \& Méon (2014) argue that when investing capital in the form of greenfield FDI, only efficient firms are able to cover costs and make profit. Greenfield FDI is mostly viewed from a positive aspect, as it usually contributes to capital increase, brings modern technology and creates new job opportunities, indicating that this form of FDI has a positive impact on economic growth. Capital investments in the form of cross-border M\&A, that implies a change of ownership over an existing firm, do not necessarily lead to an increase in the value of capital, but may mean salvation for a company threatened with bankruptcy. Although they can bring new technology, they can also close some parts and activities of an existing bought or acquired company and can affect the dismissal of a number of employees. These authors state that greenfield FDI leads to capital expansion in the host country, so its effect on economic growth is stronger than the effect of cross-border M\&A. Taking into account the differences between cross-border M\&A and greenfield FDI, the authors' research based on analysis and comparison of similarities and differences between the determinants of these two types of FDI is justified (Roberto, 2004; Neto et al., 2010; Nagano, 2013; Davies et al., 2015; Moghadam et al., 2019).

There are an enviable number of empirical papers in which authors examine determinants that affect total FDI inflows, while there are fewer empirical studies that analyze factors that only affect cross-border M\&A or greenfield FDI inflows, without comparing them (Noorbakhsh et al., 2001; Globerman \& Shapiro, 2002; Campos \& Kinoshita, 2003; Raff, 2004; DiGiovanni, 2005; Botric \& Skuflic, 2006; Kwok \& Tadesse, 2006; Bertrand \& Zitouna, 2006; Norbäck \& Persson, 2007; Sayek, 2009; Cuckovic \& Jurlin, 2009; Basile et al., 2010; Visic \& Skrabic Peric, 2011; Visic, 2012; Boateng et al., 2015; Waqas et al., 2015; Strat et al., 2015; Xie et al., 2017; Vo, 2018; Uddin et al., 2019; Krajnakova et al., 2020; Miningou \& Tapsoba, 2020).

In specifying the list of independent variables, we have included some factors that common in the papers dealing with the FDI determinants (such as inflation rate, market capitalization, human development index, openness, unemployment rate and GDP per capita), but also two variables that are not much exploated in other studies, such as quality of education system and public trust in financial honesty of politicians. In our study, it is assumed that individual factors can determine the cross-border M\&A and 
greenfield FDI activities in the same direction, while some are assumed to be able to differently affect the attraction of these two alternative types of investment. Our assumptions, as well as the results of research by other authors, are presented below in the paper.

\section{Gross Domestic Product per Capita}

GDP of a country, as a comprehensive measure of its production of goods and services, indicates the level of its economic development, which gives a signal to investors about return on investment on that location. GDP is the most important indicator of economic activity (Krajnakova et al., 2020). Examining the determinants that affect the attraction of total FDI inflows, Boateng et al. (2015) and Vo (2018) conclude that FDI inflows increase with GDP growth. Similar results are obtained by Neto et al. (2010), who show that GDP positively affects the growth of FDI inflows. These authors also find that this variable has a direct correlation with cross-border M\&A, just like Davies et al. (2015), but does not show statistical significance relative to the greenfield FDI value. On the other hand, Nagano (2013) shows the existence of a negative correlation between GDP per capita and greenfield FDI values, while Moghadam et al. (2019) and Davies et al. (2015) conclude that the GDP per capita is positively related to the greenfield FDI. However, Nagano (2013), Moghadam et al. (2019) and Visic (2012) prove that investors are interested in investing capital in the form of cross-border M\&A in countries with lower value of GDP per capita.

Based on UNCTAD data (2018), it is observed that Slovenia and Croatia with significantly higher values of GDP per capita stand out compared to Serbia and Bosnia and Herzegovina $(\mathrm{B} \& \mathrm{H})$ in the analyzed period. GDP per capita of all observed countries shows a growing trend in the 2006-2008 period. Even though there is a slight decline in the value of this variable after 2008, it records relatively stable values by the end of the analyzed period.

Given that profit is the final goal of investment, we expect an economy that achieves a satisfactory level of GDP per capita to be attractive to investors who want to invest in both cross-border M\&A and greenfield FDI.

\section{Market Capitalization}

As an important determinant reflecting capital market efficiency, market capitalization is an investment risk assessment tool for future investors. In his research on potential factors for attracting investment in the form of crossborder M\&A, DiGiovanni (2005) introduces market capitalization as an indicator of the size of the financial market and points to its positive correlation with cross-border M\&A. On the other hand, Visic \& Skrabic Peric (2011) indicate a negative impact of market capitalization on the intensity of cross-border M\&A inflows in transition countries.

Based on data collected from stock exchanges of analyzed countries (Belgrade, Sarajevo, Banja Luka, Ljubljana, Zagreb Stock Exchanges), it can be observed that Croatia is a country with significantly higher values of this indicator relative to other countries from the sample. Among the observed countries, this variable shows a declining trend since 2008, mainly due to the effects of the crisis.

We expecte a positive correlation between market capitalization and cross-border M\&A and greenfield FDI inflows, as the positive values of this indicator should contribute to increasing the value of invested capital, thus allowing investors to make profitable investments.

\section{Inflation Rate}

The inflation rate is a measure of macroeconomic stability and an indicator of monetary policy. The successful implementation of economic reforms by the host government is a good signal to investors, as stable macroeconomic effects imply lower investment risk (Campos \& Kinoshita, 2003). While assesing investments in domestic and foreign locations, according to Sayek (2009), MNC often choose not to invest capital in countries with inflation, so as not to get in a position to fight inflation problems. Waqas et al. (2015) states that inflation rates in India and China lead to higher FDI inflows and reduce investment volatility, indicating that these countries successfully manage and control inflationary processes. Visic \& Skrabic Peric (2011) point out to the oscillating statistical significance of the inflation rate influence on cross-border M\&A in their models.

According to the UNCTAD database (2018), Serbia has the highest inflation rate and the largest oscillations, while other countries have lower inflation rates, and also record more moderate differences. In 2008, the inflation rate increased in all countries compared to 2007, after which, in all countries, except Serbia, this indicator recorded relatively similar values from year to year.

Although inflation does not always pose a danger to an economy, especially if it is controlled and if the portfolio of shares is well balanced, a high inflation rate generally harms economic flows and negatively affects investments. For these reasons, lower inflation is expected to have a stimulating effect on attracting foreign capital in both crossborder M\&A and greenfield FDI.

\section{Openness}

Openness is a measure of the connection of one economy with other economies. A higher degree of openness is one of the important indicators of a larger market with a higher volume of demand. The most common measure for the level of economic openness is the overall level of foreign trade, as the sum of imports and exports relative to GDP. According to some authors (Campos \& Kinoshita, 2003; Boateng et al., 2015; Vo, 2018), the host country collects higher FDI inflows with a higher degree of openness. Positive and statistically significant correlations between openness and cross-border M\&A are indicated by Bertrand \& Zitouna (2006) and Moghadam et al. (2019). Unlike Moghadam et al. (2019), who discover negative and weak correlation between the same variable and greenfield FDI, Basile et al. (2010) point out that foreign companies place their capital in the form of greenfield FDI in countries with a larger market, i.e. where demand is higher and where there is a greater possibility of exports. 
Despite a largely positive attitude towards FDI inflows, there are concerns about their impact on development, as less developed capital markets allow investors to take over domestic firms at a too low price (Norbäck \& Persson, 2007, p. 366). Raff (2004) argues that trade liberalization does not always lead to economic benefits. Less efficient companies lose market share in the domestic market, facing increased competition. Liberalization can force a firm characterized by high fixed costs to leave the market. Even if such a firm stays in the domestic market, it is possible it will be merged by a high-tech company (Bertrand \& Zitouna, 2006, p. 482).

Based on the 2018 World Bank data, the degree of openness in all analyzed countries shows a declining trend after 2008. The values of this indicator begin to grow towards the end of the analyzed period. The country with the highest degree of trade liberalization is Slovenia.

Reduced restrictions on trade and adequate legislation indicate greater opportunities for imports and exports. Therefore, investors are expected to be actracted to invest capital in the form of cross-border M\&A and greenfield FDI in a country that is more open to foreign countries.

\section{Quality of the Education System}

Since the level of education development contributes to the economic growth of a country and indicates the existence of distinctions between national economies, the qualifications and education of the working-age population can be said to have an impact on investor decisions. As stated by Kwok \& Tadesse (2006), companies where employees have a higher level of education, the ability to learn faster and embrace advanced technologies more easily, can boast of efficiency and productivity in conducting business activities. However, these authors prove a statistically significant but negative correlation between labor force education and FDI. Campos \& Kinoshita (2003) show that the cost of labor should not be a decisive factor for investment, while Basile et al. (2010) conclude that foreign investors are discouraged by high wages of employees, which result from their high qualifications, and that they do not show interest in investing capital in the form of greenfield FDI in such countries. On the other hand, Krajnakova et al. (2020) come to the conclusion that total FDI inflows increase with the increase in employment of highly skilled workers, as is the case in the Czech Republic and Slovakia. Similar results were obtained by Miningou \& Tapsoba (2020) who prove that increasing the efficiency of the education system and the number of years of schooling, observed together, lead to an increase in FDI inflows.

According to the data from the Global Competitiveness Report (2018) of the World Economic Forum, Slovenia stands out from other countries in the sample with higher indices of quality of the education system. The quality of the education system of all observed countries shows a declining trend, especially in the post-crisis period.

Since companies are more productive and efficient in conducting business activities if they employ more capable and educated people, it is to be expected that there is a positive correlation between this factor and capital inflows in the form of cross-border M\&A and greenfield FDI.

\section{Human Development Index}

The Human Development Index (HDI) indicates the degree of physical and human infrastructure in a given country (Neto et al., 2010). Sectors with immanent employee knowledge and skills, as well as the ability to implement advanced technology, are attractive to potential foreign investors. The human capital allows access to new knowledge which helps MNC strengthen their competitive advantages. Noorbakhsh et al. (2001) conclude that the human capital index is a statistically significant determinant of FDI inflows. On the other hand, Neto et al. (2010) show that this determinant is positive and statistically significant, but only in models in which FDI, cross-border M\&A and greenfield FDI outflows appear as dependent variables.

Based on the data from the Human Development Report (2018), it is observed that Slovenia and Croatia stand out with higher indices of human capital development relative to Serbia and B\&H. This indicator shows a growing trend in the analyzed period of all observed countries, especially since 2008.

Since the level of human capital development contributes to the economic growth of the national economy, and thus to the creation of a favorable investment environment, it is expected that its growing trend will affect the increasing inflow of cross-border M\&A and greenfield FDI.

\section{Unemployment Rate}

The interdependence between FDI and labor market aspects is an important topic in the literature dealing with FDI, where the employment (unemployment) is often used as a substitute for the country's macroeconomic stability (Strat et al., 2015, p. 636). Based on the research results, Strat et al. (2015) and Botric \& Skuflic (2006) conclude that a higher unemployment rate causes a higher inflow of FDI. However, there is a risk that if unemployment rises too much, investors will lose interest in investing in a country with signs of macroeconomic instability. Basile et al. (2010) and Roberto (2004) conclude there is a direct and statistically significant correlation between the unemployment rate and the greenfield FDI.

According to the World Bank (2018) data, the unemployment rates in all countries show a downward trend until 2008, when it began to grow following the economic crisis. Its decline is also recorded in the last years of the analyzed period.

Given that the unemployment rate is one of the indicators of labor force availability in a country, it is expected that increase in the unemployment rate will make greenfield FDI more atractive, while this factor may have neutral impact on cross-border M\&A (which realization may even result in additional layoffs and the increase of unemployment).

\section{Public Trust in the Financial Honesty of Politicians}

The variables of the political system represent one of the decisive determinants for making investment decisions and define a favorable investment environment (Xie et al., 2017). Globerman and Shapiro (2002) state that public trust in the financial honesty of politicians is higher in countries with efficient, impartial and transparent legal systems that protect property and individual rights. Based on the results of the research, these authors conclude that this indicator 
favors FDI inflows. Cuckovic \& Jurlin (2009) show that companies are mainly interested in investing in countries with strong property rights protection, developed legal framework and applicable legislation, well-developed public service without red tape and corruption. Investors find it important that government policies are transparent and that there is strong protection against crime and fraud. These authors report unsatisfactory findings relating to the trust in the financial honesty of politicians and the neutrality of civil servants in Croatia and Slovenia.

As persented in the Global Competitiveness Report (2018) of the World Economic Forum, trust in the financial honesty of politicians in the analyzed period of EU member states (Croatia and Slovenia) shows a declining trend since 2008. In contrast, in Serbia and B\&H, the value of this indicator shows a growing trend in the post-crisis period.

Strong institutional laws and a favorable business environment, driven by democracy and political stability, should encourage investors to invest more in such countries in both forms of FDI (Uddin et al., 2019). We suppose that undermining trust in institutions can affect the development of distrust among investors, reduce both types of FDI inflows and thus jeopardize the country's economic growth in the selected countries.

\section{Data Collection and Research Methodology}

In order to clarify the correlation between the presented determinants and cross-border M\&A and greenfield FDI in the four former Yugoslav countries (Republic of Serbia, B\&H, Republic of Slovenia and Republic of Croatia) during the twelve-year period (2006-2017), secondary data sources were used for data collection.

The database we used for the cross-border M\&A and greenfield FDI is published by United Nations Conference on Trade and Development (UNCTAD). Availability of this database on its website allowed us to monitor the values of variables over a twelve-year period (2006-2017) and to compare them between analyzed countries. The values of cross-border M\&A and greenfield FDI inflows, given in millions of USD dollars, are scrolled by GDP per capita and expressed as a natural logarithms.

The same database is used to obtain data on GDP per capita and inflation rate. In our study, the values of GDP per capita, given in millions of US dollars, are expressed as natural logarithms. Data on inflation rates, presented as annual consumer prices indices, were not modified, but the original data were used.

In order to calculate the values of market capitalization, we used the websites of the stock exchanges of the analyzed countries - the Belgrade Stock Exchange for Serbia, the Zagreb Stock Exchange for Croatia and the Ljubljana Stock Exchange for Slovenia. Given that B\&H consists of the Federation of Bosnia and Herzegovina and the Republika Srpska, we calculated the value of the market capitalization of $\mathrm{B} \& \mathrm{H}$ as the sum of market capitalizations taken from the websites of the Sarajevo and Banja Luka Stock Exchanges. All these values refer to the stock market. To be suitable for statistical analysis, all values are expressed as natural logarithms.

We used World Bank Open Data database to calculate the openness, as the sum of imports and exports, which was put in relation to GDP and logarithmized for the purpose of statistical analysis. According to Paul \& Feliciano-Cestero (2021), imports and exports, individually observed, are frequently used determinants of FDI inflows. However, we decided to use integrated variable because we believe it is more comprehensive measure of openness. The data on the unemployment rate, as percentage of the total workforce, are also obtained from World Bank's website.

Annual Global Competitiveness Report, supplied by the World Economics Forum, publishes comprehensive financial and non-financial information on various indicators, including the global competitiveness indices in detail. We used this report to obtain the data on the index of quality of education system. From this report, we used data on the index of public trust in the financial honesty of politicians, which belongs to a group of factors that reflect the political environment and the quality of institutions. This index is calculated on the basis of the Executive Opinion Survey, which is the most comprehensive survey of its kind. It is conducted among business leaders who rank the ethical standards of politicians in their country (1 - extremely low, 7 - extremely high).

Relying on the United Nations - Human Development Report website, the indicator human development index, was used. HDI measures the average achievement in three basic dimensions of human development - long and healthy life, knowledge and a decent standard of living. Knowledge and innovation are becoming increasingly important in generating productivity growth and competitiveness, especially for MNC that have a need to harmonize the knowledge among its branches dispresed on the world market.

Data on the analyzed variables for the four countries over a twelve-year period were analyzed by correlation analysis and a panel data model, using IBM SPSS, version 17, and EViews 10. The main reasons for using the panel data model are a large number of observations that described the relation between selected variables, on one hand, and various macroeconomic variables analysed over a long period of time, on the other hand.

Like Neto et al. (2010), ordinary least square (OLS), fixed and random effect panel data model were used. Econometrically, a panel data model comprising both time series and cross-sectional elements, which means that each panel observation has a spatial and temporal dimension. Also, balanced panel data set is used which implies equal number of observations for each unit of observation (crosssection) over time. In order to select the most suitable model, we used Hausman specification test that proved the use of the random model. The results of the estimation are given using EViews 10 software.

The methodology used in this study is aimed at investigating the existance of relationship first between cross-border M\&A and selected model variables. The considered model can be presented as follows:

$$
\begin{aligned}
I M \& A / G D P p c(\log )_{i t}=\beta_{0 i} & +\beta_{1} E D U C_{i t}+\beta_{2} I N F_{i t} \\
& +\beta_{3} M C(\log )_{i t}+\varepsilon_{i t,}
\end{aligned}
$$

where $I M \& A / G D P p c(\log )$, as the dependent variable, is the logarithmic value of cross-border M\&A relative to GDP per capita, whilst the independent variables are EDUC, as the quality of the education system, $I N F$, as the inflation rate, $M C(\log )$, as the logarithimic value of market capitalization, $\beta_{0 i}$ is a random variable with a mean value of 
$\beta_{0}, e_{i t}$ is a stochastic error, $t$ is time, and $i$ is the cross-section unit ( $i^{\text {th }}$ country), and where

$$
\beta_{0 i}=\beta_{0}+v_{i}
$$

In our case, the random error $v_{i}$ is heterogeneity specific to a cross-sectional country, and it is constant over time, where is $E\left[v_{i}^{2} \mid x\right]=\sigma_{i}^{2}$.

Concerning the relationship between greenfield FDI and selected model variables, three models have been developed. They can be presented as follows:

Model 1: IGFI/GDPpc $(\log )_{i t}=\beta_{0 i}+\beta_{1} I N F_{i t}+$ $\beta_{2} E D U C_{i t}+\beta_{3} H D I_{i t}+\varepsilon_{i t}$

Model 2: IGFI/GDPpc $(\log )_{i t}=\beta_{0 i}+\beta_{1} I N F_{i t}+$

$$
\begin{gathered}
\beta_{2} \mathrm{OPEN}_{i t}+\beta_{3} U_{N E M_{i t}+\varepsilon_{i t},} \\
\text { Model 3: IGFI/GDPpc(log })_{i t}=\beta_{0 i}+\beta_{1} I N F_{i t}+ \\
\beta_{2} \text { TRUS } \\
S_{i t}+\beta_{3} G D P p c_{i t}+\varepsilon_{i t,},
\end{gathered}
$$

where in all models, IGFI/GDPpc(log), as the dependent variable, is the logarithmic value of greenfield FDI relative to GDP per capita, whilst independent variables are $I N F$, as the inflation rate, $E D U C$, as the quality of the education system, $H D I$, as the human development index, OPEN, as the openness, UNEM, as the unemployment rate, TRUS, as the public trust in financial honesty of the politicians and $G D P p c$, as the GDP per capita.

In all three models, $\beta_{0 i}$ is a random variable with a mean value of $\beta_{0}, e_{i t}$ is a stochastic error, $t$ is time, $i$ is the crosssection unit ( $i^{\text {th }}$ country), where

$$
\beta_{0 i}=\beta_{0}+v_{i}
$$

In our case, the random error $v_{i}$ is heterogeneity specific to a cross-sectional country, and it is constant over time and $E\left[v_{i}^{2} \mid x\right]=\sigma_{i}^{2}$.

\section{Results and Discussion}

\section{A Brief Overview of Cross-Border M\&A and Greenfield FDI in the Analyzed Countries}

In order to obtain a deeper understanding of determinants of the analyzed FDI modes, we first provide an insight into the trend of cross-border M\&A and greenfield FDI activity in the analyzed countries. The observed research period, from 2006 to 2017, is characterized by the existence of the global economic and financial crisis that affected both developing and developed countries. The vulnerability of economies has come to the fore since the moment of crisis development in 2008, which negatively affected various forms of capital inflow, production, inflation, exports, etc. Because of different crisis impacts on the economic indicators, the period with unstable business conditions is taken into account for analysis.

Based on UNCTAD data (Table 1), the declining trend of total FDI inflows present in the analyzed countries in the

\begin{tabular}{|c|c|c|c|c|c|c|c|c|c|c|c|c|}
\hline \multirow[b]{2}{*}{ Yr. } & \multicolumn{3}{|c|}{ Republic of Serbia } & \multicolumn{3}{|c|}{ Bosnia and Herzegovina } & \multicolumn{3}{|c|}{ Republic of Croatia } & \multicolumn{3}{|c|}{ Republic of Slovenia } \\
\hline & $\begin{array}{c}\text { FDI - } \\
\text { inflows }\end{array}$ & $\begin{array}{c}\text { Cross- } \\
\text { border } \\
\mathbf{M \& A}\end{array}$ & $\begin{array}{c}\text { Green } \\
\text { field } \\
\text { FDI } \\
\end{array}$ & $\begin{array}{c}\text { FDI - } \\
\text { inflows }\end{array}$ & $\begin{array}{c}\text { Cross- } \\
\text { border } \\
\text { M\&A }\end{array}$ & $\begin{array}{c}\text { Green } \\
\text { field } \\
\text { FDI } \\
\end{array}$ & $\begin{array}{c}\text { FDI - } \\
\text { inflows }\end{array}$ & $\begin{array}{c}\text { Cross- } \\
\text { border } \\
\text { M\&A }\end{array}$ & $\begin{array}{c}\text { Green } \\
\text { field } \\
\text { FDI } \\
\end{array}$ & $\begin{array}{c}\text { FDI - } \\
\text { inflows }\end{array}$ & $\begin{array}{c}\text { Cross- } \\
\text { border } \\
\text { M\&A }\end{array}$ & $\begin{array}{c}\text { Green } \\
\text { field } \\
\text { FDI }\end{array}$ \\
\hline 2006 & $4,255.7$ & $1,163.5$ & 3,350 & 554.7 & 78.7 & 640 & $3,290.9$ & $2,529.8$ & 536 & 706.3 & 15.1 & 656 \\
\hline 2007 & $4,405.9$ & 279.6 & 2,930 & $1,819.2$ & $1,014.1$ & 599 & $4,632.6$ & 673.9 & 1,706 & 757.3 & 56.8 & 665 \\
\hline 2008 & $3,971.9$ & 501.2 & 7,650 & $1,001.6$ & 8.9 & 1,984 & $5,317.2$ & 274.4 & 2,849 & $1,218.4$ & 417.8 & 558 \\
\hline 2009 & $2,896.1$ & 9.7 & 3,234 & 249.9 & 7.9 & 1,316 & $3,048.5$ & 237.8 & 1,526 & -475.8 & 375.1 & 289 \\
\hline 2010 & $1,686.1$ & 19.0 & 3,735 & 406.1 & 4.2 & 310 & $1,155.1$ & 201.2 & 2,305 & 105.4 & 332.3 & 638 \\
\hline 2011 & $4,932.3$ & $1,340.5$ & 3,964 & 496.5 & 4.2 & 1,235 & $1,698.7$ & 92.2 & 2,115 & $1,087.4$ & 51.2 & 459 \\
\hline 2012 & $1,298.6$ & 2.1 & 4,632 & 394.9 & 0.5 & 1,338 & $1,509.6$ & 81.2 & 1,055 & 339.3 & 330.2 & 450 \\
\hline 2013 & $2,052.5$ & 9.3 & 4,201 & 276.4 & 6.3 & 888 & 958.0 & 100.0 & 1,091 & -151.2 & 29.8 & 277 \\
\hline 2014 & $1,996.1$ & 9.8 & 2,570 & 550.2 & 9.9 & 981 & $2,877.2$ & 15.0 & 885 & $1,049.8$ & 494.6 & 202 \\
\hline 2015 & $2,346.6$ & 12.1 & 4,597 & 348.9 & 3.7 & 3,145 & 267.2 & 658.5 & 551 & $1,674.4$ & 163.1 & 151 \\
\hline 2016 & $2,350.4$ & 132.4 & 2,202 & 303.3 & 63.5 & 925 & $1,756.4$ & 107.6 & 387 & $1,260.4$ & 469.1 & 406 \\
\hline 2017 & $2,866.7$ & 80.1 & 3,729 & 425.2 & -3.3 & 668 & $2,104.2$ & 59.3 & 535 & 702.0 & 3.6 & 449 \\
\hline
\end{tabular}
2008-2011 and 2012-2013 periods is an indicator of reduced investment activity due to the crisis emergence, which is negatively reflected on the economic development in general.

Total FDI, Cross-Border M\&A and Ggreenfield FDI Inflows in the Analyzed Countries in the 2006-2017 (In Millions of \$)

Source: UNCTAD (2018), World Investment Report

After 2013, FDI began to record a slight increase compared to the previous period. The data from Table 1 show that Slovenia and Croatia, as members of the European Union, stand out from the observed groups of countries with somewhat greater values of cross-border M\&A relative to Serbia and B\&H, which maintain such a low value of these investments until the end of the analyzed period. The exception is 2011 for Serbia when an extreme inflow of this type of activity was recorded. Thanks to the package of measures for mitigating the crisis effects, which was adopted and applied by the Government of the Republic of Serbia, the dynamics of FDI inflows was renewed that year.

Serbia stood out as the country with the highest greenfield FDI performance index (Table 1). Foreign investors find this country attractive because of regulatory reform, low labor costs, shortened time for company registration and issuing of building permits. $\mathrm{B} \& \mathrm{H}$ also notes relatively satisfactory data when it comes to this type of investment, especially when the data are compared with those for Slovenia. However, compared to Serbia and Croatia, the greenfield FDI activities in B\&H are on a lower level. It can be concluded that the greenfield FDI trend in the analyzed countries is negative after 2008. Due to the crisis, weakening demand and increased competitive pressure more directed companies to preserve acquired positions and capital, and less to new investments. 


\section{What Drives Cross-Border M\&A and Greenfield FDI?}

With regard to investigation of the possible drivers of cros-border M\&A and greenfield FDI in the selected samle, we first present descriptive statistics of the dependent and independent variables (Table 2). If we look at the skewness indicators, we can conclude there are variables with a positive value. The distribution of their frequencies is positively asymmetric, i.e. the curves of these variables are asymmetric to the right. Given that the mean shows a higher value compared to the median and mode values, we can conclude that the present values are below average. This form of the curve has variables such as inflation rate, market capitalization, human development index, openness, public trust in the financial honesty of politicians and GDP per capita, which indicates that a greater number of countries from the sample achieves these significant business indicators in below-average values.

Table 2

Descriptive Statistics for the Entire Sample of Countries in the Period from 2006 to 2017

\begin{tabular}{|c|c|c|c|c|c|c|c|}
\hline & Minimum & Maximum & Mean & Standard deviation & Skewness & Kurtosis & $\mathbf{N}$ \\
\hline $\begin{array}{l}\text { Cross-border M\&A } \\
\text { relative to GDP per } \\
\text { capita }(\log )\end{array}$ & 0.00 & 5.42 & 3.7523 & 0.97644 & -1.070 & 3.483 & 48 \\
\hline $\begin{array}{l}\text { Greenfield FDI } \\
\text { relative to GDP per } \\
\text { capita }(\log )\end{array}$ & 3.81 & 6.42 & 5.0887 & 0.67323 & -0.061 & -1.065 & 48 \\
\hline Inflation rate & -1.13 & 12.41 & 2.9921 & 3.38874 & 1.166 & 0.904 & 48 \\
\hline $\begin{array}{l}\text { Quality of the } \\
\text { education system }\end{array}$ & 2.36 & 4.48 & 3.4383 & 0.51413 & -0.034 & -0.538 & 48 \\
\hline $\begin{array}{l}\text { Market capitalization } \\
(\log )\end{array}$ & 9.70 & 10.90 & 10.0394 & 0.28091 & 0.813 & 0.176 & 48 \\
\hline $\begin{array}{l}\text { Human development } \\
\text { index }\end{array}$ & 0.70 & 0.90 & 0.7996 & 0.05853 & 0.239 & -1.073 & 48 \\
\hline Openness & 0.23 & 1.40 & 0.8167 & 0.25393 & 0.431 & -0.342 & 48 \\
\hline $\begin{array}{l}\text { Public trust in the } \\
\text { financial honesty of } \\
\text { politicians }\end{array}$ & 1.53 & 3.36 & 2.2454 & 0.41365 & 0.933 & 0.940 & 48 \\
\hline Unemployment rate & 4.39 & 31.10 & 17.3838 & 7.42124 & -0.048 & -1.003 & 48 \\
\hline GDP per capita & 3.62 & 4.41 & 3.9796 & 0.29903 & 0.200 & -1.752 & 48 \\
\hline
\end{tabular}

Source: Authors' calculation

In the further research procedure, correlation analysis was applied to determine the strength and direction of the linear correlation between the variables (Table 3 and Table 4). The data from Table 3 indicate that of the eight independent variables analyzed, three showed a direct but relatively weak correlation with the cross-border M\&A value relative to GDP per capita. These are: inflation rate, quality of the education system and market capitalization.

Table 3

Matrix of Correlation with Cross-border M\&A Value for the Entire Sample of Countries in the Period from 2006 to 2017

\begin{tabular}{|c|c|c|c|c|c|c|c|c|c|}
\hline & 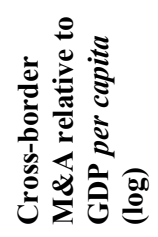 & & 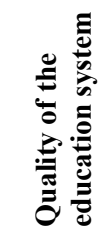 & 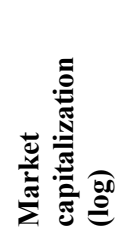 & 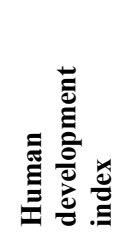 &  & 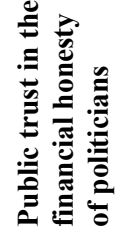 & 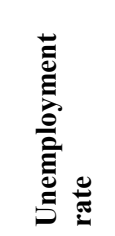 & 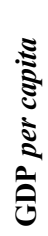 \\
\hline $\begin{array}{l}\text { Cross-border M\&A relative to } \\
\text { GDP per capita }(\log )\end{array}$ & 1 & & & & & & & & \\
\hline Inflation rate & $0.324^{*}$ & 1 & & & & & & & \\
\hline Quality of the education system & $0.364^{*}$ & 0.220 & 1 & & & & & & \\
\hline Market capitalization (log) & $0.401^{* *}$ & 0.128 & 0.224 & 1 & & & & & \\
\hline Human development index & -0.013 & $-0.330^{*}$ & $0.601^{* *}$ & 0.067 & 1 & & & & \\
\hline Openness & -0.216 & $-0.375^{* *}$ & $0.382^{* *}$ & $-0.467^{* *}$ & $0.571^{* *}$ & 1 & & & \\
\hline $\begin{array}{l}\text { Public trust in the financial } \\
\text { honesty of politicians }\end{array}$ & -0.089 & -0.157 & $0.470^{* *}$ & 0.062 & $0.470^{* *}$ & $0.353^{*}$ & 1 & & \\
\hline Unemployment rate & -0.100 & 0.097 & $-0.723^{* *}$ & -0.187 & $-0.897^{* *}$ & $-0.436^{* *}$ & $-0.527^{* *}$ & 1 & \\
\hline GDP per capita & 0.066 & $-0.338^{*}$ & $0.636^{* *}$ & $0.305^{*}$ & $0.942^{* *}$ & $0.514^{* *}$ & $0.480^{* *}$ & $-0.866^{* *}$ & 1 \\
\hline
\end{tabular}

**. The correlation is statistically significant at the 0.01 level (2-tailed).

*. The correlation is statistically significant at the 0.05 level (2-tailed). 
The data from Table 4 indicate a significant statistical correlation with the greenfield FDI relative to GDP per capita in seven of the eight analyzed variables, namely: inflation rate, quality of the education system, human development index, openness, public trust in the financial honesty of politicians, unemployment rate and GDP per capita.

Matrix of Correlation with Greenfield FDI Value for the Entire Sample of Countries in the Period from 2006 to 2017

\begin{tabular}{|c|c|c|c|c|c|c|c|c|c|}
\hline & 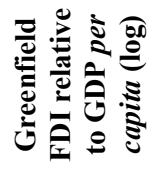 & 氖 & 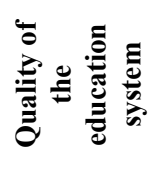 & 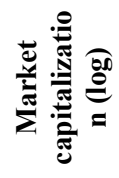 & 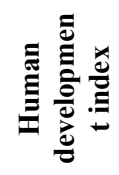 & 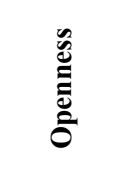 & 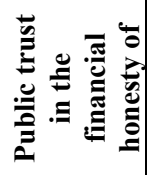 &  & ڤั \\
\hline $\begin{array}{l}\text { Greenfield FDI } \\
\text { relative to GDP } \\
\text { per capita }(\log )\end{array}$ & 1 & & & & & & & & \\
\hline Inflation rate & $0.523^{* *}$ & 1 & & & & & & & \\
\hline $\begin{array}{l}\text { Quality of the } \\
\text { education system }\end{array}$ & $-0.486^{* *}$ & 0.220 & 1 & & & & & & \\
\hline $\begin{array}{l}\text { Market } \\
\text { capitalization } \\
(\log )\end{array}$ & -0.150 & 0.128 & 0.224 & 1 & & & & & \\
\hline $\begin{array}{l}\text { Human } \\
\text { development } \\
\text { index }\end{array}$ & $-0.798^{* *}$ & $-0.330^{*}$ & $0.601^{* *}$ & 0.067 & 1 & & & & \\
\hline Openness & $-0.637^{* *}$ & $-0.375^{* *}$ & $0.382^{* *}$ & $-0.467^{* *}$ & $0.571^{* *}$ & 1 & & & \\
\hline $\begin{array}{l}\text { Public trust in the } \\
\text { financial honesty } \\
\text { of politicians }\end{array}$ & $-0.332^{*}$ & -0.157 & $0.470^{* *}$ & 0.062 & $0.470^{* *}$ & $0.353^{*}$ & 1 & & \\
\hline $\begin{array}{l}\text { Unemployment } \\
\text { rate }\end{array}$ & $0.667^{* *}$ & 0.097 & $-0.723^{* *}$ & -0.187 & $-0.897^{* *}$ & $-0.436^{* *}$ & $-0.527^{* *}$ & 1 & \\
\hline GDP per capita & $-0.862^{* *}$ & $-0.338^{*}$ & $0.636^{* *}$ & $0.305^{*}$ & $0.942^{* *}$ & $0.514^{* *}$ & $0.480^{* *}$ & $-0.866^{* *}$ & 1 \\
\hline
\end{tabular}

Since the correlation analysis provides only an overview of the existence of statistically significant correlations between variables, in the further procedure we will apply panel analysis, described in the previous section, to determine their quantitative dependence. The first model was formed as a function of the dependent variable - the logarithmic value of cross-border M\&A relative to GDP per capita with regard to the three independent ones that showed a certain correlation with it, as shown in equation (1). An identical procedure was performed in the situation in which a logarithmic greenfield FDI is taken as a dependent variable relative to GDP per capita and in which a statistical correlation of seven independent variables with the dependent one was identified. Within this model, we introduced three different models to track the change in the value of the dependent variable relative to a different combination of independent variables, as shown in equations (2), (3) and (4).

Based on empirical evidence, it can be concluded that the inflation rate and the quality of the education system in the analyzed countries are factors that jointly determine cross-border M\&A and greenfield FDI. We also find that the variable market capitalization is significant only for attracting capital in the form of cross-border M\&A, and, on the other side, HDI, openness, unemployment rate, public trust in financial honesty of politicians and GDP per capita are variables that are significant only for greenfield FDI.

Table 5

Random Effects Model for Cross-Border M\&A Data

\begin{tabular}{|l|c|c|c|}
\hline & Coefficient & t-Statistic & Sig. \\
\hline (Constant) & -9.084 & -2.070 & 0.044 \\
\hline Quality of the education system & 0.460 & 1.853 & 0.071 \\
\hline Inflation rate & 0.066 & 1.793 & 0.080 \\
\hline Market capitalization (log) & 1.101 & 2.461 & 0.018 \\
\hline R Square & 0.290 & & \\
\hline Adjusted R Square & 0.242 & & 0.2162 \\
\hline Hausman Test & \multicolumn{2}{|c|}{4.456284} & \\
\hline
\end{tabular}

Dependent variable: logarithmic value of cross-border M\&A relative to GDP per capita 
Random Effects Model for Greenfield FDI Data

\begin{tabular}{|c|c|c|c|c|c|c|c|c|c|}
\hline & \multicolumn{3}{|c|}{ Model 1} & \multicolumn{3}{|c|}{ Model 2} & \multicolumn{3}{|c|}{ Model 3} \\
\hline & 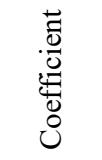 & 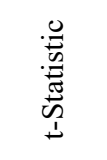 & $\dot{00}$ & 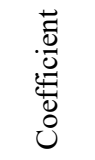 & 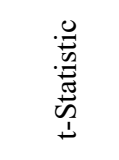 & $\stackrel{000}{\infty}$ & 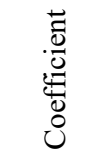 & 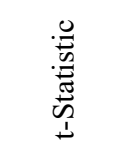 & $\stackrel{\dot{00}}{\tilde{n}}$ \\
\hline (Constant) & 10.585 & 17.043 & 0.000 & 4.658 & 20.076 & 0.000 & 11.938 & 21.977 & 0.000 \\
\hline Inflation rate & 0.085 & 5.844 & 0.000 & 0.074 & 5.907 & 0.000 & 0.052 & 4.433 & 0.000 \\
\hline $\begin{array}{l}\text { Quality of the education } \\
\text { system }\end{array}$ & -0.379 & -3.353 & 0.002 & & & & & & \\
\hline Human development index & -5.561 & -5.415 & 0.000 & & & & & & \\
\hline Openness & & & & -0.729 & -3.963 & 0.000 & & & \\
\hline Unemployment rate & & & & 0.046 & 7.904 & 0.000 & & & \\
\hline $\begin{array}{l}\text { Public trust in the financial } \\
\text { honesty of politicians }\end{array}$ & & & & & & & 0.171 & 1.660 & 0.104 \\
\hline GDP per capita & & & & & & & -1.856 & -12.442 & 0.000 \\
\hline R Square & \multicolumn{3}{|c|}{0.750} & \multicolumn{3}{|c|}{0.709} & \multicolumn{3}{|c|}{0.813} \\
\hline Adjusted R Square & \multicolumn{3}{|c|}{0.733} & \multicolumn{3}{|c|}{0.690} & \multicolumn{3}{|c|}{0.800} \\
\hline Hausman Test & \multicolumn{2}{|c|}{5.725} & 0.126 & & & 0.098 & & & 0.191 \\
\hline
\end{tabular}

Dependent variable: logarithmic value of greenfield FDI relative to GDP per capita

The research results show that the inflation rate has a statistically significant and direct correlation with the value of both forms of FDI (Table 5 and Table 6). In this regard, our research results coincide with the results obtained by Waqas et al. (2015), taking as a dependent variable the value of total FDI inflows. Investors who decide to invest in a country with a certain inflation rate should be prepared for more demanding business conditions than those in a stable environment. The real estate and stocks tend to be undervalued in the developing countries that are exposed to inflationary flows. Also, investors often invest in index portfolios of stocks that show a tendency to relatively quickly adjust to the real value after inflationary shocks, in just a few years as a rule. Companies can defend themselves against the negative effects of inflation by diversifying investments, thus spreading risk, as an instrument of protection against inflationary processes. With a well-diversified portfolio, even medium-high inflation should not be an obstacle to investment, but can prove to be a good decision along with relatively stable other macroeconomic indicators.

While examing the importance of inflation for the two FDI modes, it is worth indicating its significance for the formation of exchange rates. The increase in the general price level prevents the impact of the depreciation of the national currency on the increase in exports. In that case, the nominal exchange rate rises, but due to the increase in the inflation rate, the real exchange rate decreases, as evidenced by Ali et al. (2015). Monetary instability through the growth of the exchange rate can cause further price increases and devaluation-inflation spiral. The inefficiency of the depreciation of the national currency indicated that a policy of a stable exchange rate is necessary in order to achieve macroeconomic stability (Markovic \& Markovic, 2014) and the FDI growth. According to Cushman \& De Vita (2017), a relatively fixed exchange rate regime affects the increase in FDI inflows, while this is not the case with a fluctuating exchange rate. Regardless of the different exchange rate regimes, analyzed countries in our study managed to deal with the stabilization of the inflation rate. These results are especially important for Serbia and B\&H, given that both countries are striving to become members of the European Union, where maintaining price stability is the primary task of monetary policy. The fixed exchange rate regime applied in $\mathrm{B} \& \mathrm{H}$ and Croatia contributed to the stabilization of the inflation rate and lower values in relation to Serbia, which chose the fluctuating exchange rate regime. Serbia is a country characterized by a high degree of correlation between inflation and the exchange rate, because of importdependent economy. There is a high degree of elasticity, so changes in the exchange rate are quickly reflected in prices. Since inflation also has a reciprocal effect on the exchange rate, the key to success is to maintin exchange rate stability and general price levels. In inflationary conditions, the exchange rate becomes unrealistic, so the economy cannot be competitive for FDI.

Although our assumption was that there would be a positive correlation between the quality of the education system and both modes of FDI capital inflows, the research results show that this relationship is positive only in the case of cross-border M\&A value (Table 5), while it takes negative sign when observed the greenfield FDI value (Model 1, Table 6). Basile et al. (2010) obtain similar results while considering the correlation between the quality of the education system and the greenfield FDI, and Krajnakova et al. (2020) and Miningou \& Tapsoba (2020) find that the value of total FDI increases with the increase of this indicator. Why investors in the greenfield FDI in the analyzed countries do not find the high labor force qualification and education crucial determinants? Generally speaking, greenfield FDI are a more expensive and risky investments, and they seek cheaper labor in return. Furthermore, as it is confirmed in the sample countries, investors are not willing to invest in countries with relatively high wages, as they pursue a "low cost" policy. On the other hand, cross-border M\&A allows large companies to become even larger, making their financial strength superior. The 
investment risk in cross-border M\&A activities in the analyzed former SFRY countries, appears to be relatively low, since foreign investor mainly direct their external growth strategies toward companies with monopolistic or oligopolistic position at the domestic market. With the growth of educated and skilled labor force, investors become more willing to increase nominal wages, motivated precisely by the qualifications and productivity of their employees.

The assumption about positive correlation between market capitalization and capital inflows based on crossborder M\&A and greenfield FDI, is confirmed only in the case of cross-border M\&A (Table 5), which coincides with the results obtained by DiGiovanni (2005). As investing in the form of cross-border M\&A is a form of ownership restructuring, new owners find information about the possibilities of increasing their invested capital important, which can be seen through this indicator. In addition to being one of the indicators of size and turnover on the stock market, market capitalization also gives investors the opportunity to observe the perception of investment risk as it helps to choose ways to diversify the portfolio to achieve long-term financial goals. As our results show, this is especially true in shallow and less liquid capital markets, such as those that make up the research sample.

Our findings show that the former SFRY countries attract a lower level of greenfield FDI because of the higher level of GDP per capita (Model 3, Table 6). The negative correlation between GDP per capita and greenfield FDI, which is in line with Nagano (2013) study, can be explained by different factors: the business and various strategies used in this process by the analyzed countries, the country's protectionist policy aimed at banks and companies during the transition process against "potential danger" called foreign capital. Visic (2012) came to similar results, but when cross-border M\&A activities are considered as a dependent variable. The markets in which above-average profits are realized, due to the higher value of GDP, face increased and saturated local competition, and investors are not interested in placing capital on such markets.

The analysis shows that investors are more willing to invest capital in the form of greenfield FDI, if the degree of openness is lower (Model 2, Table 6), which is in the accordance with Moghadam et al. (2019) findings. Increased liberalization may lead to a steep increase in imports, which could result in excessive competition in certain sectors, as well as domestic market saturation. Therefore, it should be borne in mind that any additional liberalization of the market and economy carries certain risks and dangers (Raff, 2004; Bertrand \& Zitouna, 2006). One of the concerns about the impact of cross-border M\&A on economic development is that underdeveloped capital markets allow foreign investors to take over domestic firms at a too low price. Cross-border M\&A, unlike greenfield FDI, do not lead to an increase in the number of firms and production capacities, which can have a negative impact on social welfare. As Norbäck \& Persson (2007) point out, some markets restrict the right of foreign investors and firms to buy domestic enterprises or impose special restrictions on investors in certain industries.

The results show that with the decline in human development index, investors show a greater willingness to invest in the form of greenfield FDI (Model 1, Table 6). Our results confirm that investors investing capital in the form of greenfield FDI in the analyzed countries find extremely low labor costs important, which is, unfortunately, not favorable for the host country economy. Also, when it comes to investing in a foreign country, the different nature of the local environment and national differences can affect the inability of employees to adapt to the way of doing business and employment of a foreign employer, which makes achieving satisfactory performance in this case, and ultimately capital inflows, missing (Weber \& Tarba, 2010, p. 206).

Empirical results show that investors are willing to invest their capital in greenfield FDI activities where there is a higher unemployment rate (Model 2, Table 6). When it comes to greenfield FDI, our results are consistent with the results of research conducted by Basile et al. (2010) and Roberto (2004), and similar results were obtained by Botric \& Skuflic (2006) and Strat et al. (2015), but when it comes to total FDI.

The analysis shows that investors will choose to invest in the greenfield FDI if public trust in the honesty of politicians is greater (Model 3, Table 6). Globerman \& Shapiro (2002) and Cuckovic \& Jurlin (2009) come to similar results, but when the total FDI value is considered as a dependent variable. In the case of selected former SFRY countries, it is particularly important for investors that government policies are transparent, that there is strong protection against crime and fraud, high protection of property rights, developed legal framework and applicable legislation, well-developed public service without red tape, excessive regulation and corruption.

\section{Conclusion}

This paper, focused on the analysis of the factors that drive cross-border M\&A and greenfield FDI in the former SFRY countries, led us to several conclusions.

Firsty, uncertain capital market, increased overall business risk and financial system instability, caused by the global crisis, resulted in a logical decline in the value of both forms of FDI in the post-crisis period, which particularly affected transition countries where capital is a necessary condition for development. The results show that economies, with increased caution of multinational companies, slowly begin to recover in the late years of the analyzed period in terms of attracting FDI, which have a special dimension and importance when it comes to the countries in the sample. However, the road to recovery is thorny and may take longer than expected.

Secondy, when the economy is in transition and when there is a chronic lack of capital that questions not only the development but sometimes the survival of the economy, any form of foreign capital is a saving solution. In order for a country to think about attracting capital, it must have a healthy investment environment, which will, in addition to foreign ones, also motivate domestic investors to invest in the economy of a particular country.

Thirdly, our study reveals some specific and unexpectied relationship between the two modes of FDI and some macroeconomic variables. The findings indicate that the quality of the education system impacts differently cross-border M\&A and greenfield FDI, while the selected countries with lower quality of education system are more attractive to greenfield investors. The inflation rate is 
directly statistically correlated with the activities of both forms of foreign direct investment, which confirms that investors invest in economies characterized by a certain macroeconomic instability, i.e. they do not perceive inflationary trends as a disadvantage. Futhermore, investors are more willing to realize greenfield FDI, if the degree of openness of the host economy is lower, protecting themselves in this way from high competition and possible saturation of the domestic market.

Finally, the research results point out that some macroeconimic factors determine only particular form of foreign investments. Namely, the value of market capitalization is a statistically significant determinant that affects the attraction of foreign capital exclusively in the form of cross-border M\&A in the analyzed countries. On the other hand, factors such as the human development level, openness, GDP per capita, public trust in the financial honesty of politicians, as well as the unemployment rate are only drivers of greenfield FDI.

The evidence provided in this study is relevant to decisions aiming at improving the effectiveness of policy makers in creating favorable, healthy and stable business environment for both forms of FDI. The aspiration of national economies towards forming a stimulating investment environment motivates multinational companies that have a strategic approach to the realization of long-term profitability. However, the results indicate that even a less favorable business environment is not an obstacle for shortterm investors, who are willing to take a relatively higher level of risk in such business conditions.

In the end, we should also outline some limitations of this research. The limitation of this study is the length of the period for analysis (2006-2017), since the database for individual analyzed determinants was available in this period. Also, due to the limited availability of certain data, the remaining two countries of the former SFRY (North Macedonia and Montenegro) could not be included in the analysis. Another limitation is the relatively small sample (48) used in the panel analysis. The following research could be extended to other economies in the Balkans, such as Bulgaria, Hungary, Romania and Albania. Also, the following study could include other forms of FDI, for example, joint ventures and brownfield investments, to consider and compare the determinants of attracting foreign capital in more detail.

\section{References}

Ali, T. M., Mahmood, M. T., \& Bashir, T. (2015). Impact of Interest Rate, Inflation and Money Supply on Exchange Rate Volatility in Pakistan. World Applied Sciences Journal, 33(4), 620-630. https://doi.org/10.5829/idosi. wasj.2015.33.04.82

Aliber, R. Z. (1970). A theory of direct foreign investment. C.P. Kindleberger (ed.), The International Corporation. MIT Press, Cambridge, MA, United States.

Banja Luka Stock Exchange. Retrieved from https://blberza.com/Pages/annualreports.aspx. Accessed on: 15 September 2018.

Basile, R., Benfratello, L., \& Castellani, D. (2010). Location determinants of greenfield foreign investments in the enlarged Europe: Evidence from a spatial autoregressive negative binomial additive model. Working paper, 10. Università di Torino.

Belgrade Stock Exchange. Retrieved from https://www.belex.rs/trgovanje/izvestaj/godisnji. Accessed on: 15 September 2018.

Bertrand, O., \& Zitouna, H. (2006). Trade Liberalization and Industrial Restructuring: The Role of Cross-Border Mergers and Acquisitions. Journal of Economics \& Management Strategy, 15(2), 479-515. https://doi.org/10.1111/j.15309134.2006.00108.x

Boateng, A., Hua, X., Nisar, S., \& Wu, J. (2015). Examining the determinants of inward FDI: Evidence from Norway. Economic Modelling, 47, 118-127. https://doi.org/10.1016/j.econmod.2015.02.018

Botric, V., \& Skuflic, L. (2006). Main Determinants of Foreign Direct Investment in the Southeast European Countries. Transition Studies Review, 13(2), 359-377. https://doi.org/10.1007/s11300-006-0110-3

Buckley, P. J., \& Casson, M. (1976). A long-run theory of the multinational enterprise. In: The Future of the Multinational Enterprises. Macmillan, London. https://doi.org/10.1007/978-1-349-02899-3

Cai, D., \& Karasawa-Ohtashiro, Y. (2018). Greenfield, mergers and acquisition, or export? Regulating the entry multinational enterprises to a host-country market. International Review of Economics and Finance, 56 (2018), 397407. https://doi.org/10.1016/j.iref.2017.11.008

Campos, N. F., \& Kinoshita, Y. (2003). Why does FDI go where it goes? New evidence from the transition economies. International Monetary Fund, IMF Institute, IMF Working Paper, 03/228. https://doi.org/10.5089/9781451875461.001

Cuckovic, N., \& Jurlin, K. (2009). Determinants of Competitiveness and Economic Governance: Some Evidence from the new EU member states and Croatia. 2009 Biannual EUSA Conference, Los Angeles, California, 23-25 April 2009. Available from internet: http://aei.pitt.edu/33046/.

Cushman, D. O., \& De Vita, G. (2017). Exchange rate regimes and FDI in developing countries: A propensity score matching approach. Journal of International Money and Finance, 77, 143-163. https://doi.org/10.1016/j.jimonfin.2017.07.018

Davies, R. B., Desbordes, R., \& Ray, A. (2015). Greenfield versus Merger \& Acquisition FDI: Same Wine, Different Bottles? Working Paper No. 39, Paris School of Economics. Available from internet: https://halshs.archivesouvertes.fr/halshs-01122659 
Ksenija Dencic Mihajlov, Vinko Lepojevic, Jovana Stojanovic. What Drives Cross-Border Mergers and Acquisitions ...

DiGiovanni, J. (2005). What drives capital flows? The case of cross-border M\&A activity and financial deepening. Journal of International Economics, 65, 127-149. https://doi.org/10.1016/j.jinteco.2003.11.007

Dunning, J. H. (1979). Explaining Changing Patterns of International Production: In Defence of the Eclectic Theory. Oxford Bulletin of Economics and Statistics, 41(4), 269-295. https://doi.org/10.1111/j.1468-0084.1979.mp41004003.x

Globerman, S., \& Shapiro, D. (2002). Global Foreign Direct Investment Flows: The Role of Governance Infrastructure. World Development, 30(11), 1899-1919. https://doi.org/10.1016/S0305-750X(02)00110-9

Harms, P., \& Meon, P.G. (2014). Good and bad FDI: The growth effects of greenfield investment and mergers and acquisitions in developing countries. Centre Emile Bernheim, Research Institute in Management Sciences. Working Paper No. 14/021.

Helpman, E. (1984). A simple theory of international trade with multinational corporations. Journal of Political Economy, 92(3), 451-471. https://doi.org/10.1086/261236

Hymer, S. H. (1976). The International Operations of National Firms: A Study of Direct Foreign Investment. Cambridge: MIT Press.

Kindleberger, C. P. (1969). American Business Abroad. Yale University Press, New Haven, CT, United States. https://doi.org/10.1002/tie.5060110207

Kojima, K., \& Ozawa T. (1985). Toward a theory of industrial restructuring and dynamic comparative advantage. Hitotsubashi Journal of Economics, 26(2), 135-145.

Krajnakova, E., Pilinkiene, V., \& Bulko, P. (2020). Determinants of Economic Development and Employability of Higher Education Institutions Graduates. Inzinerine Ekonomika-Engineering Economics, 31(2), 211-220. http://dx.doi.org/10.5755/j01.ee.31.2.24751

Kwok, C., \& Tadesse, S. (2006). The MNC as an Agent of Change for Host-Country Institutions: FDI and Corruption. William Davidson Institute Working Paper, 882. https://doi.org/10.1057/palgrave.jibs.8400228

Ljubljana Stock Exchange. Retrieved from http://www.ljse.si/cgi-bin/jve.cgi?doc=8226. Accessed on: 15 September 2018 .

Markovic, I., \& Markovic, M. (2014). Uticaj transmisionog mehanizma deviznog kursa na konkurentnost izvoza Srbije [The impact of the exchange rate transmission mechanism on the competitiveness of Serbian exports]. Ekonomske teme, 52(2), 205-221.

Miningou, E. W., \& Tapsoba, S. J. (2020). Education systems and foreign direct investment: does external efficiency matter? Journal of Applied Economics, 23(1), 583-599. https://doi.org/10.1080/15140326.2020.1797337

Moghadam, A. T., Mazlan, N. S., Chin, L., \& Ibrahim, S. (2019). Mergers and Acquisitions and Greenfield Foreign Direct Investment in Selected ASEAN Countries. Journal of Economic Integration, 34(4), 746-765. https://doi.org/10.11 130/jei.2019.34.4.746

Nagano, M. (2013). Similarities and differences among cross-border M\&A and greenfield FDI determinants: Evidence from Asia and Oceania. Emerging Markets Review, 16 (2013), 100-118. https://doi.org/10.1016/j.ememar.2013.04.001

Nayak, D., \& Choudhury, R. N. (2014). A selective review of foreign direct investment theories. ARTNeT Working Paper Series, No. 143, Asia-Pacific Research and Training Network on Trade (ARTNeT), Bangkok.

Neto, P., Brandao, A., \& Cerqueira, A. (2010). The Macroeconomic Determinants of Cross-Border Mergers and Acquisitions and Greenfield Investments. IUP Journal of Business Strategy, 7(1), 21-57.

Nocke, V., \& Yeaple, S. (2008). An Assignment Theory of Foreign Direct Investment. Review of Economic Studies, 75(2), 529-557. https://doi.org/10.1111/j.1467-937X.2008.00480.x

Noorbakhsh, F., Paloni, A., \& Youssef, A. (2001). Human Capital and FDI Inflows to Developing Countries: New Empirical Evidence. World Development, 29(9), 1593-1610. https://doi.org/10.1016/S0305-750X(01)00054-7

Norbäck, P. J., \& Persson, L. (2007). Investment liberalization - Why a restrictive cross-border merger policy can be counterproductive. Journal of International Economics, 72 (2), 366-380. https://doi.org/10.1016/j.jinteco.2006.09.004

Paul, J., \& Feliciano-Cestero, M. M. (2021). Five decades of research on foreign direct investment by MNEs: An overview and research agenda. Journal of Business Research, 124 (2021), 800-812. https://doi.org/10.1016/j.jb usres.2020.04.017

Raff, H. (2004). Preferential trade agreements and tax competition for foreign direct investment. Journal of Public Economics, 88(12), 2745-2763. https://doi.org/10.1016/j.jpubeco.2004.03.002

Roberto, B. (2004). Acquisition versus greenfield investment: the location of foreign manufacturers in Italy. Regional Science and Urban Economics, 34 (1), 3-25. https://doi.org/10.1016/S0166-0462(02)00073-X

Sarajevo Stock Exchange. Retrieved from http:/www.sase.ba/v1/Izvje\%C5\%A1taji/Ostali-izvje\%C5\%A1taji/Godi\%C5\% A1nji- izvje\%C5\%A1 taji. Accessed on: 15 September 2018.

Sayek, S. (2009). Foreign Direct Investment and Inflation. Southern Economic Journal, 76(2), 419-443. https://doi.org/10. 4284/sej.2009.76.2.419 
Strat, V. A., Davidescu, A., \& Raul, A. M. (2015). FDI and the Unemployment - A Causality Analysis for the Latest EU Members. Procedia Economics and Finance, 23, 635-643. https://doi.org/10.1016/S2212-5671(15)00448-7

The World Bank. Retrieved from https://data.worldbank.org/indicator. Accessed on: 11 September 2018, various years.

Uddin, M., Chowdhury, A., Zafar, S., Shafique, S., \& Liu, J. (2019). Institutional determinants of inward FDI: Evidence from Pakistan. International Business Review, 28 (2), 344-358. https://doi.org/10.1016/j.ibusrev.2018.10.006

UNCTAD, (2018). World Investment Report: Annex Tables. Retrieved from http://unctad.org/en/Pages/DIAE/World\%20 Investment\%20Report/Annex-Tables.aspx. Accessed on: 10 September 2018.

UNCTAD, (2018). Retrieved from https://unctadstat.unctad.org/wds/TableViewer/tableView.aspx. Accessed on: 10 September 2018.

United Nations Development Programme, Human Development Report. Retrieved from http://hdr.undp.org/en/data. Accessed on: 11 September 2018, various years.

Vernon, R. (1966). International trade and international investment in the product cycle. Quarterly Journal of Economics, 80(2), 190-207. https://doi.org/10.2307/1880689

Visic, J. (2012). Evidence of Fire-Sale M\&A in European Transition Countries. Managing Global Transitions, 10(4), 325-340.

Visic, J., \& Skrabic Peric, B. (2011). The determinants of value of incoming cross-border mergers \& acquisitions in European transition countries. Communist and Post-Communist Studies, 44 (3), 173-182. https://doi.org/10.1016/j.postco mstud.2011.07.004

Vo, X. V. (2018). Determinants of capital flows to emerging economies - Evidence from Vietnam. Finance Research Letters, 27 (2018), 23-27. https://doi.org/10.1016/j.frl.2018.02.031

Waqas, Y., Hashmi, S. H., \& Nazir, M. I. (2015). Macroeconomics factors and foreign portfolio investment volatility: A case of South Asian countries. Future Business Journal, 1 (1/2), 65-74. https://doi.org/10.1016/j.fbj.2015.11.002

Weber, Y., \& Tarba, S.Y. (2010). Human resource practices and performance of mergers and acquisitions in Israel. Human Resource Management Review, 20(3), 203-211. https://doi.org/10.1016/j.hrmr.2009.08.007

World Economic Forum. The Global Competitiveness Report. Retrieved from https://www.weforum.org/reports. Accessed on: 10 September 2018, various years.

Xie, E., Reddy, K. S., \& Liang, J. (2017). Country-specific determinants of cross-border mergers and acquisitions: A comprehensive review and future research directions. Journal of World Business, 52(2), 127-183. https://doi.org/10.1016/j.jwb.2016.12.005

Zagreb Stock Exchange. Retrieved from https://www.zse.hr/default.aspx?id=44325. Accessed on: 15 September 2018.

\section{Authors' biographies}

Ksenija Denčić-Mihajlov is a Full Professor at the Faculty of Economics, University of Nis, Republic of Serbia. Besides teaching Business Finance and International Business Finance according to accredited program of undergraduate studies, she is a professor in Strategic Financial Management and Business and Financial Restructuring at master level and Financial Strategy of Corporate Companies at graduate level. Her key areas of scientific research interest are sustainable finance and socially responsible investment, corporate financing and restructuring.

Vinko Lepojević is a Full Professor of Statistics at Faculty of Economics, University of Nis, Republic of Serbia. He holds a MS degree in Statistics from Faculty of Economics, Belgrade University, and PhD from Faculty of Economics, University of Nis, Republic of Serbia. His research interests are application of mathematical and statistical methods in economic research and the application of statistical methods in market research. His research works have been published in international journals and also in the highly regarded national journals.

Jovana Stojanović is a PhD student in the Department of Accounting at the Faculty of Economics, University of Nis, Republic of Serbia. She is currently a junior researcher at the Innovation Center, University of Nis and non-employment associate in International Business Finance, Management Accounting and Cost Accounting at the Faculty of Economics. Her research interests are in the areas of accounting, financial reporting, auditing and financial management.

The article has been reviewed. Received in August 2020; accepted in June 2021.

This article is an Open Access article distributed under the terms and conditions of the Creative Commons Attribution 4.0 (CC BY 4.0) License (http://creativecommons.org/licenses/by/4.0/). 